\title{
Stem cell nations working together for a stem cell world
}

\section{"To achieve a one stem cell world, rather than divided stem cell nations, now is the time to reach out beyond national boundaries for the benefit of all."}

Stem cell-based therapies, tools and targets are our future. The potential to impact on so many different diseases, disorder and injuries virtually guarantees that at some point in everyone's life, the benefits of stem cell technology will be felt. The big challenge for the stem cell community is therefore to facilitate the best possible interaction with the population at large. This means locally, nationally and internationally one world. This issue of Regenerative Medicine includes three highly relevant and timely papers covering several of the major global challenges to the future of cell-based therapies: stem cell tourism [1], emerging stem cell nations [2] and the facilitation of genuine dialogue and engagement with the public, regardless of location, in order to advance responsible stem cell research across the world [3]. These three topics are all highly intertwined since they cross the important divide between the stem cell community and the general public by addressing directly the asynchronous distribution of knowledge and understanding that presently exists. The ability to distinguish between reality, and 'hype and hope', is a major challenge for stem cell professionals let alone the lay public [4].

\section{Promoting global dialogue \& public engagement}

Knoppers et al. in their paper, highlight the goals of the newly launched 'Stem Cell Charter' [3]. The Charter is an interactive web-based activity that affirms the importance of stem cell research for people everywhere. It was devised under the auspices of the Canadian Stem Cell Foundation by bioethicist Bartha Maria Knoppers (McGill University, Canada) in collaboration with a working group of stem cell scientists, patients, ethicists and laypeople [101]. Regenerative Medicine fully endorses the five principles outlined in the Charter: responsible research, protection of the public, intellectual freedom, transparency and integrity. This international people's stem cell charter perfectly complements the existing global initiatives to raise public awareness and stimulate responsible public discussion. These include the California Institute for Regenerative Medicine (CIRM) initiated Stem Cell Awareness Day (23rd September) [5] and the outreach activities of the International Society for Stem Cell Research (ISSCR), Hinxton Group [6] and the Genetics Policy Institute (GPI) [7].

\section{Stem cell tourism}

Medical tourism is on the rise [8-10] and the need for reliable sources of appropriate knowledge has never been greater than in the complex area of stem cell tourism. The stem cell research community are acutely aware of this challenge, hence the growing number of working groups, initiatives and reports on the topic including the ISSCR 'Guidelines for the Clinical Translation of Stem Cells' [11]. The Stem Cell Charter is therefore particularly timely in that it moves the stem cell tourism debate further down the value chain to the public by squarely endorsing responsibility, protection and integrity amongst its core principles. Much has already been published on this growing area of 'directto-consumer' cell-based therapies [12]. However, the Ryan et al. paper in this issue [1] is the first to track the rise of stem cell tourism. The big concern for the stem cell research community is "that administering unproven stem cell interventions outside a carefully regulated clinical trial puts individual patients at risk and also jeopardizes the legitimate progress of translational stem cell research" [11]. Stem cell tourism is a phenomenon unwittingly facilitated by uneven global regulation and enforcement. Medical tourism, of which stem cell tourism is still a relatively small but fast growing component, is a difficult market to quantify. It is widely acknowledged that a substantial number of patients travel to developing nations for healthcare [9]. For example, it is suggested that 750,000 Americans will

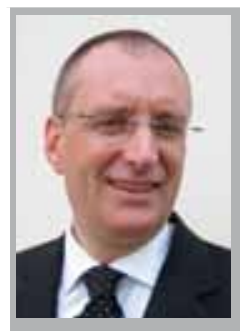

Chris Mason

Author for correspondence: Advanced Centre for Biochemical Engineering, University College London, Roberts Building, Torrington Place, London, WC1E 7JE, UK Tel.: +44 2076790140 ; Fax: +44 207209 0703, chris.mason@ucl.ac.uk

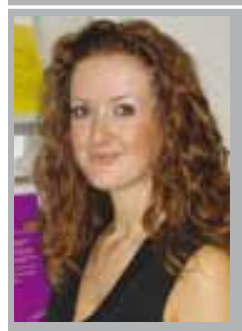

Elisa Manzotti

Future Medicine Ltd,

Unitec House, 2 Albert Place, Finchley Central, London, N3 1QB, UK

Tel.: +442083716090;

Fax: +44 208343 2313;

e.manzotti@

futuremedicine.com;

www.futuremedicine.com

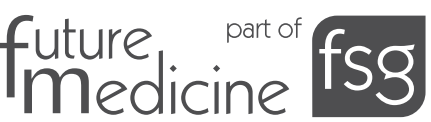


have gone offshore for medical services in 2007 increasing to 6 million in 2010 [102] worth an estimated \$40-60 billion [103]. The value of the stem cell tourism market is unknown, although Lau $e t$ al. in 2008 suggested that the average cost per cell-based therapy was in the order of $\$ 20,000$ excluding travel and accommodation for the patients and caregivers [12]. Patient choice lies at the heart of healthcare, therefore the right of a patient to travel for innovative or proven stem cell-based therapies must remain [13]. Health tourism may represent one final last chance, however remote the possibility of success. The challenge for everyone is to be able to distinguish between unethical stem cell exploitation and legitimate attempts at innovative stem cell-based interventions or even proven therapies [13]. The issues are not limited solely to under-informed or overly optimistic patients since the wider society is now beginning to embrace medical tourism. In several states in the USA, the Blue Cross Blue Shield Association promotes insurance policies that enable patients to have expensive medical procedures at low-cost offshore medical facilities [103-107]. Even Fortune 500 corporations are evaluating the feasibility of outsourcing the more costly medical procedures to offshore establishments [14]. Against this overall tide of change, it is futile for the stem cell nations to sit like King Canute and command the waves to go back [108]. Medical tourism is permanently changing the healthcare landscape and will continue to evolve [9]. Tracking the changes with respect to cell-based therapies will enable the community to better understand the requirement for appropriate actions to mitigate the risks posed by stem cell tourism both to patients as well as the future of the legitimate global regen industry $[1,15]$.

\section{Emerging stem cell nations}

Thomas Friedman in his book, 'The world is flat: A brief history of the twenty-first century' has suggested that whilst the physical world is unquestionably round, with respect to technology it is however flattening [109]. Whilst this is certainly true for information technology (IT) and partially true for biotechnology [110], it is not yet the case for cell therapies. Friedman's rationale for the technology earth becoming flattened include several 'forces' that hold good for both IT and biotech and are now just beginning to enter the cell therapy domain. These include: outsourcing, offshoring (especially with respect to stem cell tourism [16]), supplychaining and the ease of global interconnectivity via the internet - all activities which allow individuals and companies to collaborate and share knowledge [110]. The challenge of this flattening environment has not gone unnoticed by the US biotech sector, the world's most dominant biotechnology nation. The founding of biotech start-up companies in the USA has slowed whilst the opposite is occurring in Asia and Europe, biotech clusters which were once the hallmark of entrepreneurial biotech in the US are thriving everywhere and Indian contract research organisations (CROs) and contract manufacturing organisations (CMOs) are booming [110] . Flattening is further accelerated by large numbers of US-trained Chinese ('sea turtles') and Indian scientists returning back to their country of origin [110] coupled to the widening 'numbers gap' - in 2001, compared with the USA, India graduated almost one million more students and China has six times as many graduates in engineering [109-111]. Whilst the US still has advantages; its high level of R\&D, the US FDA being the prevailing regulatory authority and the high prices obtainable in North America on biotech products, even these are being eroded by both national and international pressures. Unlike biotech, cell therapies have entered directly into a flattening world and have been subject to no other existence. However, there are still major areas where the position is far from flat including the complex issues surrounding national regulations and ethics. President Bush's stance on human embryonic stem cells allowed a number of other nations to seize the stem cell initiative and to build a lead [17]. As a result, Australia, Canada [18], Sweden and the UK have all built substantial infrastructure, talent pools and momentum. The developed world is not alone in progressing cell-based therapies, other emerging stem cell nations are now fast appearing including Japan [19], India [20,112] and China [2,21,113]. Thorsteinsdóttir et al. in this issue [2] conclude that "China has been able to catapult itself into the forefront of regenerative medicine" but this has been in part due to the uneven global regulatory environment. A situation that is now beginning to start to be resolved [22] but will no doubt remain a significant issue for both ethical stem cell tourism and for the global distribution, marketing and clinical acceptance of proven cell therapy products for the foreseeable future.

The stem cell world will continue to flatten with the process being accelerated by organizations such as GPI, International Consortium of Stem Cell Networks, International Society for Cellular Therapy, International Stem Cell 
Forum, ISSCR and Tissue Engineering \& Regenerative Medicine International Society - all of whom are bringing the global stakeholders together to further legitimate research and translation. Funding is always the major challenge to international collaborations, however, bold initiatives are starting to appear, for example the collaborative funding agreement between CIRM and the Chinese Ministry of Science and Technology [114,115]. Such relationships optimize global resources, avoid duplication and help create the necessary critical mass to successfully develop and delivery cell-based therapies regardless of geographical location [115]. Stem Cell Awareness Day and the Stem Cell Charter go the next step by actively encouraging everyone, especially the public, to be genuinely involved with stem cell technology not just within the existing stem cell nations but globally. These empowering activities will undoubtedly have a direct impact on the future of both stem cell tourism and emerging stem cell nations. To achieve a one stem cell world, rather than divided stem cell nations, now is the time to reach out beyond national boundaries for the benefit of all.

\section{Financial \& competing interests disclosure}

The authors have no relevant affiliations or financial involvement with any organization or entity with a financial interest in or financial conflict with the subject matter or materials discussed in the manuscript. This includes employment, consultancies, honoraria, stock ownership or options, expert testimony, grants or patents received or pending, or royalties.

No writing assistance was utilized in the production of this manuscript.

\section{Bibliography}

1 Ryan AR, Sanders AN, Wang DD, Levine AD: Tracking the rise of stem cell tourism. Regen. Med. 5(1), 27-33 (2010).

2 McMahon DS, Thorsteinsdóttir $\mathrm{H}$, Singer PA, Daar AS: Cultivating regenerative medicine innovation in China. Regen. Med. 5(1), 35-44 (2010).

3 Knoppers BM, Isasi R, Willemse L: Stem Cell Charter. Regen. Med. 5(1), 5-6 (2010).

4 Qiu J: Trading on hope. Nat. Biotechnol. 27(9), 790-792 (2009).

5 Wong KM: Culturing stem cell awareness. Cell Stem Cell 5, 470-471 (2009).

6 Savulescu J, Saunders R: The "Hinxton Group" considers transnational stem cell research. Hastings Cent. Rep. 36(3), 1 p following 48 (2006).

7 Siegel B: Organization profile: genetics policy institute. Regen. Med. 4(3), 365-370 (2009).

8 Regenberg AC, Hutchinson LA, Schanker B, Mathews DJ: Medicine on the fringe: stem cell-based interventions in advance of evidence. Stem Cells 27(9), 2312-2319 (2009).

9 Horowitz MD, Rosensweig JA, Jones CA: Medical tourism: globalization of the healthcare marketplace. MedGenMed 9(4), 33 (2007).

10 Arunanondchai J, Fink C: Trade in health services in the ASEAN region. Health Promot Int. 21(Suppl. 1), 59-66 (2006).

11 Hyun I, Lindvall O, Ahrlund-Richter L et al.: New ISSCR guidelines underscore major principles for responsible translational stem cell research. Cell Stem Cell 3(6), 607-609 (2008).
12 Lau D, Ogbogu U, Taylor B, Stafinski T, Menon D, Caulfield T: Stem cell clinics online: the direct-to-consumer portrayal of stem cell medicine. Cell Stem Cell 3(6), 591-594 (2008).

13 Lindvall $\mathrm{O}$, Hyun I: Medical innovation versus stem cell tourism. Science 324(5935), 1664-1665 (2009).

14 Schult J: Beauty from Afar: A Medical Tourist's Guide to Affordable and Quality Cosmetic Care Outside the U.S. Stewart, Tabori \& Chang, NY, USA (2006).

15 Mason C, Manzotti E: Regen: the industry responsible for cell-based therapies. Regen. Med. 4(6), 783-785 (2009).

16 Kiatpongsan S, Sipp D: Medicine. Monitoring and regulating offshore stem cell clinics. Science 323(5921), 1564-1565 (2009).

17 Herrera S: Leaders and laggards in the stem cell enterprise. Nat. Biotechnol. 23(7), 775-777 (2005).

18 Willemse L, Lyall D, Rudnicki M: Catalyzing stem cell research. Regen. Med. 3(5), 761-764 (2008).

19 Brevignon-Dodin L, Livesey F: What can be learnt from the Japanese regulatory approach to tissue engineered products? Regen. Med. 2(6), 967-971 (2007).

20 Salter B, Cooper M, Dickins A, Cardo V: Stem cell science in India: emerging economies and the politics of globalization. Regen. Med. 2(1), 75-89 (2007).

21 Salter B, Cooper M, Dickins A: China and the global stem cell bioeconomy: an emerging political strategy? Regen. Med. 1(5), 671-683 (2006).
22 Sipp D: The rocky road to regulation. Nat. Rep. Stem Cells (2009) (Epub ahead of print).

\section{Websites}

101 Stem Cell Network becomes founding signatory to the Stem Cell Charter 22nd September 2009. www.stemcellnetwork.ca/uploads/news/ Charterlaunch09-09.pdf

102 Medical tourism is the new wave of outsourcing from India Harish Baliga 23 December, 2006.

www.indiadaily.com/editorial/14858.asp

103 Employers make a push for 'medical tourism'. Walecia Konrad, CNNMoney/FSB Magazine 15 May 2007: 4:00 PM EDT. http://money.cnn.com/magazines/fsb/fsb_ archive/2007/05/01/100003808/index.htm

104 Aleccia J: Hip surgery in India? Insurance may pay. msnbc 30/06/08. www.msnbc.msn.com/id/25415614/ns/ health-health_care/

105 Appleby J, Schmit J: Sending patients packing. USA Today $9 / 8 / 06$. www.usatoday.com/money/industries/ health/2006-07-26-travel-surgery-usat_x. htm

106 WellPoint Introduces International Medical Tourism Pilot Program 12 November, 2008. www.bcbs.com/news/plans/wellpointintroduces.html

107 Van Dusen A: Outsourcing your health 22/5/07.

www.forbes.com/2007/05/21/outsourcingmedical-tourism-biz-cx_ avd_0522medtourism.html 
108 Cnut the Great, Wikipedia.

http://en.wikipedia.org/wiki/Cnut_the_ Great

109 Friedman TL: It's a Flat World, After All. 3 April, 2005.

www.nytimes.com/2005/04/03/ magazine/03DOMINANCE.html

110 Rosen M: The flattening world and its impact on U.S. biotech. 30 August, 2006. http://wistechnology.com/articles/3279/
111 Bill Gates: National Governors Association, Achieve Summit Prepared Remarks 26 February, 2005. www.nga.org/cda/files/es05gates.pdf

112 Jayakumar PB: India Inc finds stem cells a healthy business. Business Standard/Mumbai 14 July, 2009, 0:35 IST. www.business-standard.com/india/news/ india-inc-finds-stem-cellshealthybusiness/363866/

113 University of Minnesota MBBNet, World Stem Cell Map. www.mbbnet.umn.edu/scmap.html
114 China and California announce collaboration to advance stem cell research toward cures. 19 October, 2009. www.cirm.ca.gov/PressRelease_101909

115 California Institute for Regenerative Medicine. CIRM Collaborative Funding. www.cirm.ca.gov/Collaborative_funding 